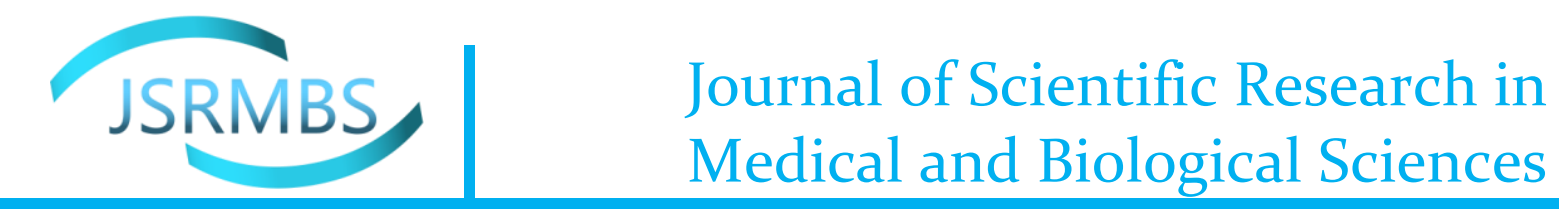

ISSN 2709-0159(print) and ISSN 2709-1511 (online)

Volume 2, Issue 4

Research Article

DOI: https://doi.org/10.47631/jsrmbs.v2i4.332

\title{
THE COMPARISON BETWEEN REPRODUCTIVE PERFORMANCE IN SYNCHRONIZED AND SPONTANEOUS ESTRUS SHEEP
}

\author{
Hawar M. H. Zebari ${ }^{1}$ \\ ${ }^{1}$ Department of Animal Production, College of Agricultural Engineering Sciences, University of \\ Duhok, Duhok, Kurdistan Region, Iraq
}

\section{ARTICLE INFO}

Received: 19 August 2021

Revised: 31 October 2021

Accepted: 31 October 2021

Keywords:

Ewes Sheep, Productivity

Abortion, Fertility, Lambing

Corresponding Author:

Hawar M. H. Zebari

Email:

hawar.mikahil@uod.ac

Copyright (C) 2021 by author(s) and Journal of Scientific Research in Medical and Biological Sciences.

This work is licensed under the Creative Commons Attribution International License (CC BY 4.0). http://creativecommons.org/licenses/ by/4.0/

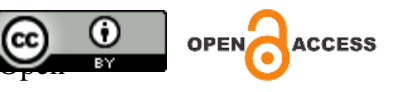

\begin{abstract}
Purpose: The objective of the present study was to compare the reproductive performance in synchronized and spontaneous estrus sheep raised under farm conditions.

Subjects and Method: Two hundred Karadi and Two hundred Awassi were used in this study. Of each breed, 100 ewes were allowed to come in estrus spontaneously and the other 100 ewes were synchronized using intravaginal sponges (ESPONJAVET, HIPRA, Amer, Girona, SPAIN). Ewes were injected with intramuscular injection of 500 IU of PMSG when sponges were removed on day 14 .

Results: This study revealed that estrus synchronization had a higher rate of lambing $(P=0.014)$, twining $(P<0.001)$, dystocia $(P=0.024)$, and barrenness $(P=0.012)$ in Karadi ewes. Estrus synchronization also had a significantly higher rate of lambing $(P=0.018)$, twining $(P=0.017)$, abortion $(P<0.001)$, barrenness $(P=0.012)$ and productivity $(P=0.010)$ in Awassi ewes. the result of the current study shows that the barrenness rate was higher in spontaneously ovulated ewes compared to synchronized Awassi ewes. The result of the current study shows that the abortion rate was higher in spontaneous ewes compared to synchronized ewes. The twinning rate was higher in synchronized compared to spontaneous Karadi ewes.

Conclusion: In both breeds, synchronized ewes had higher reproductive efficiency compared to ewes that had spontaneous estrus.
\end{abstract}

\section{INTRODUCTION}

Recently, there has been an increasing interest in the understanding of the influence of some factors on productivity efficiency in sheep. Therefore, to maintain high reproductive performance in Karadi and Awassi sheep flocks under traditional conditions, identifying factors that influence reproductive efficiency is critically important (Juma \& Alkass, 2005; Lafi et al., 2009; Zebari et al., 2018). Karadi and Awassi are the local breed of sheep in the Kurdistan region and Iraq (Alkass \& Abdulkareem, 2004), and are considered the most important sheep breed in the semi-arid regions of the near east countries (Galal et al., 2008). The local breeding season 
starts as early as April and lasts through September (Oramari et al., 2014). The reproductive performance of Kardi and Awassi sheep has been low (Juma \& Alkass, 2005).

During the breeding season, intravaginal progestogen sponges, followed by pregnant mare serum gonadotropin (PMSG) injection were applied to ewes to synchronize estrous (Mutiga \& MukasaMugerwa, 1992) and to improve the ovulation rate (Tetsuka et al., 1988). Intravaginal progestogen sponges are usually inserted over a period of 12-14 days followed by injection of PMSG, especially during the non-breeding season in sheep (Wildeus, 1997; Ungerfeld \& Rubianes, 2002). The factors that influence the fertility of Karadi and Awassi are unclear (Zebari, 2020). In the reproductive planning of sheep, spontaneous versus synchronized estrus ewe are factors that have a great effect on fertility results (Buckley et al., 2003). Conception rate (Alkass \& Abdulkareem, 2004; Zebari, 2019), litter size or percentage of lambs born to ewe lambed (Abdulkareem \& Eidan, 2014), the number of ewe lambed, abortion, parturition dystocia and mortality rate after birth are considered the main aspects in sheep reproductive performance (Evans, 2003).

In general, productivity and profitability can be determined by the reproductive performance of sheep. Fertility in sheep is influenced by hormonal status (Taha \& Alkass, 2011) and breeding programs; spontaneous versus synchronized estrus (Crosby et al., 1991). There are limited studies that reported the effect of the breeding programs on the reproductive efficiency in Iraqi native sheep (Zebari, 2020). However, there is also a paucity of published information on the factors that influence reproductive performance in Karadi and Awassi sheep raised under farm conditions. Therefore, the present study was designed to investigate whether the reproductive performance of Karadi and Awassi sheep raised under farm conditions are affected by spontaneous versus synchronized estrus ewes

\section{METHODOLOGY}

The experiment was undertaken between June 2020 and July 2021 at three traditional sheep farms in Sharmin, Akre, Duhok Governorate. The Animal Production Department Research Ethics Committee approved the research protocol in the College of Agricultural Engineering Sciences, University of Duhok.

\section{Experimental Animal, Housing and Management}

Four hundred Karadi and Awassi sheep (200 Karadi and 200 Awassi) with parity $2.7 \pm 1.3$ were used at three traditional sheep farms in Akre, Duhok Governorate. At the start of the study, the sheep (Ewe and Rams) were submitted for detection of any abnormalities of the reproductive tract. Sheep were kept with the main flock. The sheep were housed in a free-stall yard during night and sheep were put out to graze during the day (06:00 to 20:00) in the summer months and continuously housed during winter. During housing, total mixed ration (TMR; hay, barley and wheat barn) was provided daily, sufficient for ad libitum availability. Water was also provided ad libitum from water troughs at the free stall yard and pasture during the summer.

\section{Estrus Synchronization}

Each Karadi and Awassi ewes were randomly divided into two groups. The first group ( $\mathrm{n}=100$ Karadi and $n=100$ Awassi ewes) were allowed for coming into estrus spontaneously. The second group ( $n=100$ Karadi and $n=100$ Awassi ewes) were synchronized using intravaginal sponges composed of polyurethane sponge soaked with $60 \mathrm{mg}$ of medroxyprogesterone acetate/sponge (ESPONJAVET, HIPRA, Amer, Girona, SPAIN). The sponges were introduced with the aid of an applicator which was disinfected before each use. The sponge remained in the vagina of the 
ewe for 12 to 14 days then the sponges were removed at day 14 of the anestrus stage. Ewes were injected with intramuscular injection of 500 IU of PMSG (ESPONJAVET, HIPRA, Amer, Girona, SPAIN). The injections were carried out on day 14 after the withdrawal of the vaginal sponges. The active fertile rams were introduced to ewe $48 \mathrm{hrs}$ after the removal of sponges (ram to ewe ratio; $1: 15)$.

\section{Data Collection}

\section{Reproductive Parameters}

Fertility rate, conception rate, litter size (prolificacy), lambing (\%), twinning rate, abortion rate, dystocia rate, lamb mortality rate after birth to weaning, barrenness and productivity were calculated according to Taha and Alkass (2011) as below; (1) Fertility rate $=($ No. of ewes lambed / no. of ewes exposed to ram) x 100; (2) Conception rate $=$ (No. of ewes lambed + aborted $/$ no. of ewes exposed to ram) x 100; (3) Litter size (Prolificacy) $=$ No. of lamb born / no. of ewes lambed; (4) Lambing rate $=($ No. of lamb born / no. of ewes exposed to ram $) \times 100$; (5) Twining rate $=($ No. of lamb born twins / no. of ewes exposed to ram $) \times 100 ;(6)$ Abortion rate $=($ No. of ewes aborted / no. of ewes exposed to ram) x 100; (7) Dystocia rate $=($ No. of ewes lambed with dystocia / no. of ewes lambed) $x 100$; (8) Lamb mortality rate $=$ (No. of lamb died / no. lamb weaned) $x$ 100; (9) Barrenness rate $=$ (No. of ewes failed to lamb / no. of ewes exposed to ram) x 100; (10) Productivity = Fertility X Prolificacy X survival rate or (No of lambed weaned / no. of ewes exposed to ram) $\mathrm{x} 100$

\section{Spontaneous Versus Synchronized Estrus}

Each Karadi and Awassi ewes were randomly divided into two groups. The first group $(n=100$ Karadi and $n=100$ Awassi ewes) were allowed for coming into estrus spontaneously. The second group ( $\mathrm{n}=100$ Karadi and $n=100$ Awassi ewes) was synchronized using intravaginal sponges according to ESPONJAVET-HIPRA company. These were used to analyze the effect of spontaneous versus synchronized estrus on the reproductive performance of ewes.

\section{Statistical Analysis}

Statistical analyses were performed using the Genstat statistical software package (Genstat 18th edition, 18.1.14713, VSN International Ltd, UK). All of the data sets analyzed were normally distributed. Chi-Square tests were used to compare reproductive parameters (0/1) of the fertility rate, conception rate, abortion rate, dystocia rate, lamb mortality rate from birth to weaning, barrenness and productivity between synchronizes versus spontaneous estrus ewes. Chi-Square tests were also used to compare reproductive performance (1/2) of litter size, laming rate and twining rate between synchronizes versus spontaneous estrus ewes. Differences were reported as significant at $\mathrm{P}<0.05$ and trends were reported when $\mathrm{P}$ is between $<0.1$ and $>0.05$

\section{RESULTS AND DISCUSSION}

\section{Spontaneous Vs. Synchronized Karadi Ewes}

Regarding the effect of spontaneous and synchronized on reproductive efficiency in Karadi sheep, the rate of lambing $(\mathrm{P}=0.014)$, twining $(\mathrm{P}<0.001)$ and dystocia $(\mathrm{P}=0.024)$ were higher in synchronized ewes compared to spontaneous ewes (107 vs 84\%, 25.88 vs $7.69 \%$ and $4.7 v s$ $1.0 \%$, respectively). Productivity rate were also trended to be higher $(\mathrm{P}=0.063)$ in synchronized $(106 \%)$ compared to spontaneous $(84 \%)$ ewes. However, the rate of barrenness ewes were more $(\mathrm{P}=0.012)$ in spontaneous Karadi ewes $(18.0 \%)$ compared to synchronized Karadi ewes $(10.0 \%)$. There were no differences in the rate of fertility $(P=202)$, conception (0.102), litter size or prolificacy $(\mathrm{P}=0.115)$, abortion $(\mathrm{P}=0174)$ and lamb mortality rate $(\mathrm{P}=$ $0.116)$ between synchronized and spontaneous ewes (Table 1). 
Table 1. Effect of spontaneous and synchronization estrus on reproductive performance in Karadi $(n=200)$ ewes.

\begin{tabular}{|c|c|c|c|}
\hline \multicolumn{4}{|c|}{ Karadi sheep $(n=200)$} \\
\hline \multirow[t]{2}{*}{ Reproductive traits } & $\begin{array}{c}\text { Spontaneous estrus } \\
\text { ewes }(n=100)\end{array}$ & $\begin{array}{l}\text { Synchronized estrus ewes } \\
(n=100)\end{array}$ & \multirow[t]{2}{*}{$P$ value } \\
\hline & Number $(\%)$ & Number $(\%)$ & \\
\hline Fertility rate & $78 / 100(78 \%)$ & $85 / 100(85 \%)$ & 0.202 \\
\hline Conception rate & $82 / 100(82 \%)$ & $90 / 10(90 \%)$ & 0.103 \\
\hline Litter size or prolificacy & $84 / 72(1.07)$ & $107 / 85(1.26)$ & 0.115 \\
\hline Lambing \% & $84 / 100(84 \%)$ & $107 / 100(107 \%)$ & 0.014 \\
\hline Twining rate & 6/78 (7.69\%) & $22 / 85(25.88 \%)$ & 0.001 \\
\hline Abortion rate & $4 / 100(4 \%)$ & $5 / 100(5 \%)$ & 0.174 \\
\hline Dystocia rate & $1 / 78(1.3 \%)$ & 4/85 (4.7) & 0.024 \\
\hline Mortality rate after birth & $0 / 84(0.0 \%)$ & $1 / 107(0.09 \%)$ & 0.116 \\
\hline Barrenness\% & $18 / 100(18.0 \%)$ & $10 / 100(10.0 \%)$ & 0.012 \\
\hline Productivity $\%$ & $84 / 100(84 \%)$ & $106 / 100(106 \%)$ & 0.063 \\
\hline
\end{tabular}

\section{Spontaneous vs synchronized Awassi ewes}

The differences between reproductive efficiency between synchronized and spontaneous Awassi ewes are presented in Table 2 . Lambing rate $(\mathrm{P}=0.018)$, twining rate $(\mathrm{P}=0.017)$ and productivity $(\mathrm{P}=0.010)$ were higher in synchronized Awassi ewes compared to spontaneous Awassi ewes (116 vs 90\%, 27.5 vs $12.5 \%$ and 112 vs 88\%, respectively). However, abortion rate $(\mathrm{P}<0.001)$ and barrenness rate $(\mathrm{P}=0.012)$ were more in spontaneous ewes compared to synchronized ewes (5.0 vs $3.0 \%$ and $15.0 \%$ vs $6.0 \%$, respectively). The results show no differences in the rate of fertility $(\mathrm{P}=0.192)$, conception $(\mathrm{P}=0.297)$, litter size or prolificacy $(\mathrm{P}=0.415)$, dystocia $(\mathrm{P}=107)$ and lamb mortality rate from birth to weaning $(\mathrm{P}=0.174)$ between synchronized Awassi ewes and spontaneous Awassi ewes (Table 2)

Table 2. Effect of spontaneous and synchronization estrus on reproductive performance in Awassi $(n=200)$ ewes.

\begin{tabular}{cccc}
\hline \multicolumn{4}{c}{ Awassi sheep (n=200) } \\
\hline & $\begin{array}{c}\text { Spontaneous estrus } \\
\text { ewes (n=100) } \\
\text { Number (\%) }\end{array}$ & $\begin{array}{c}\text { Synchronized estrus ewes } \\
(\mathbf{n = 1 0 0})\end{array}$ & P value \\
Reproductive traits & $80 / 100(80 \%)$ & $91 / 100(91 \%)$ & 0.192 \\
& $85 / 100(85 \%)$ & $94 / 100(94 \%)$ & 0.297 \\
\hline Fertility rate & $90 / 80(1.12)$ & $116 / 91(1.27)$ & 0.415 \\
Conception rate & $90 / 100(90 \%)$ & $116 / 100(116 \%)$ & 0.018 \\
Litter size or prolificacy & $10 / 80(12.5 \%)$ & $25 / 91(27.5 \%)$ & 0.017 \\
Lambing \% & $5 / 100(5 \%)$ & $3 / 100(3 \%)$ & 0.001 \\
Twining rate & $1 / 80(1.3 \%)$ & $2 / 91(2.2 \%)$ & 0.107 \\
Abortion rate & $2 / 90(2.2 \%)$ & $4 / 116(0.34 \%)$ & 0.174 \\
Dystocia rate & $15 / 100(15 \%)$ & $6 / 100(6 \%)$ & 0.012 \\
Mortality rate after birth & $88 / 100(88 \%)$ & $112 / 100(112 \%)$ & 0.01 \\
Barrenness\% & & & \\
Productivity \% &
\end{tabular}

\section{Spontaneous vs synchronized Karadi ewes}

As expected, the result of the current study shows that the lambing rate was more in synchronized Karadi ewes compared to spontaneous Karadi ewes. Similarly, Abdulkareem and Eidan (2014) and Quintero-Elisea et al. (2011) found lambing rate in synchronized ewes $(100 \%)$ higher than spontaneous ewes $(66.7 \%)$. The lambing rate in synchronized Karadi ewes of the present study is within the range (97-123\%) reported by Abecia et al. (2007) in three 
sheep breeds in Spain raised under farm conditions. The result of the current study was higher than that found by Crosby et al. (1991) who recorded a $72 \%$ of lambing rate in synchronized ewes using progesterone treatments. In addition, the result of the current study lambing rate was higher than that recorded by Berhan and Van Arendonk (2006) of $81 \%$ vs $76 \%$ in Menz and Horro, respectively. However, the result of the present study lambing rate in spontaneous Karadi ewes of this study is lower than that reported by Taha and Alkass (2011) of 86.5\% spontaneous Karadi ewes. The lambing rate in spontaneous Karadi of the present study also is lower than that found by Binns et al. (2002) of $96 \%$ in UK sheep breeds.

In addition, the results of the present study found that the twinning rate was higher in synchronized compared to spontaneous Karadi ewes. This finding is consistent with those found by Abdulkareem and Eidan (2014) of twinning rate (18.75\% vs 6.66 in synchronized and spontaneous, respectively) in Iraqi native sheep. The result of the present also agrees with the report by Quintero-Elisea et al. (2011) who found that the twinning rate was higher in synchronized $30 \%$ compared to spontaneously ovulated ewes (22\%). Alongside with higher lambing rate and twinning rate, the productivity rate in synchronized ewes was also trended to be higher compared to spontaneous Karadi ewes. Higher lambing and twinning rate in synchronized ewes may be due to the persistent dominant follicle was regressed during progestogen treatment and a new follicle was ovulated at progesterone withdrawal (Gazal et al., 1998). This will lead to a higher ovulation rate and ovum quality (Abdulkareem \& Eidan, 2014).

Furthermore, the result of the present study revealed that the rate of dystocia was higher in synchronized ewes compared to spontaneous Karadi ewes. Similarly, Rawlings and Howell (1988) and Sánchez et al. (2008) found that dystocia rate in synchronized ewes was higher than that of the spontaneously ovulating sheep. The result of the present study of synchronized ewes is within the range (3.53-10.58) as found by Mandal et al. (2007) Muzaffarnagar sheep. A higher percentage of dystocia in synchronized ewes may be due to a higher rate of twinning in synchronized ewes compared to spontaneous ewes (Mandal et al., 2007). According to the Australian report, twin lambs effect on dystocia rate and there is a positive relationship between the twinning rate and the rate of dystocia in sheep (Hailat et al., 1997).

However, in the present study, the rate of barrenness ewes was recorded more in spontaneous Karadi ewes compared to synchronized Karadi ewes. These results are in agreement with those reported by Abdulkareem and Eidan (2014) of barrenness rate $(21.4 \%$ vs $7.55 \%$ in synchronized and spontaneous, respectively) in Iraqi native sheep. Lower barrenness rate in synchronized ewes than spontaneously estrus ewes may be due to more strength of estrus in synchronized ewes of sustained growth of the largest follicle at day 14 after the withdrawal of the vaginal sponges which lead to subluteal level induced by the exogenous treatment and an increase in LH concentration (Leyva et al., 1998; Quintero-Elisea et al., 2011).

\section{Spontaneous vs synchronized Awassi ewes}

The results of the present study found that lambing rate and twining rate were higher in synchronized Awassi ewes compared to spontaneous Awassi ewes. These findings are in agreement with those of Abdulkareem and Eidan (2014) who found lambing rate and twinning rate in synchronized Awassi ewes were higher in comparison to spontaneous Awassi sheep. However, the lambing rate in synchronized and spontaneously ovulated Awassi ewes of the present study were higher than those (82.9-100.0\%) reported by Juma and Alkass (2005) in Awassi sheep. While the twinning rate in the present study of the spontaneously ovulated Awassi ewes was lower than those reported by Juma and Alkass (2005) of 12.3 to $13.7 \%$ in Awassi sheep. Higher lambing and twinning rate in synchronized Awassi ewes may be due to 
higher ovulation rate and ovum quality and consequently an increase in lambing and twinning rate in synchronized sheep (Gazal et al., 1998; Abdulkareem and Eidan, 2014). Different lambing and twinning rate in various studies may be due to the effect of environmental and management factors (Binns et al., 2002). Productivity was higher in synchronized Awassi ewes compared to spontaneous Awassi ewes. This finding is consistent with those found by Juma and Alkass (2005) and Abdulkareem and Eidan (2014). The higher productivity in synchronized ewes compared to spontaneously ovulated Awassi ewes may be due to the higher lambing rate and twinning rate in synchronized ewes.

In healthy sheep herds, the normal proportion of aborting ewes is generally between $2 \%$ and $5 \%$ (Menzies, 2011). The result of the current study shows that the abortion rate was higher in spontaneous ewes compared to synchronized ewes. These findings are in agreement with the finding of Beck et al. (1993) who found that the abortion rate was higher in synchronized ewes compared to spontaneously ovulated Awassi ewes (8\% and 2\%, respectively). The reasons of the higher abortion rate in spontaneously ovulated ewes compared to synchronized Awassi ewes are unclear and need more investigations. The abortion rate in the present study is within the range reported by (Mahboub et al., 2013) of 1-25\% in three Egypt sheep raised under farm conditions.

As expected, the result of the current study shows that the barrenness rate was higher in spontaneously ovulated ewes compared to synchronized Awassi ewes. This result is consistent with that found by Abdulkareem and Eidan (2014) reported that the barrenness rate in synchronized (21.4\%) was higher than spontaneously ovulated (7.55\%) in Awssi ewes raised under farm conditions in the middle and south of Iraq. Lower barrenness rate in synchronized ewes than spontaneously estrus ewes may be due to sustained growth of the largest follicle at day 14 after the withdrawal of the vaginal sponges which lead to subluteal level induced by the exogenous treatment and an increase in LH concentration (Leyva et al., 1998). This leads to higher estrus activity in synchronized ewes which can be detected easily by rams during the breeding season and consequently an increase in pregnancy rate (Quintero-Elisea et al., 2011)

\section{CONCLUSION}

In both breeds' synchronized ewes had her reproductive efficiency compared to ewes that came into estrus spontaneously under traditional farm conditions.

\section{ACKNOWLEDGEMENTS}

The authors would like to thank the owner of the farms for their support

\section{CONFLICT OF INTEREST}

The author declares no conflict of interest.

\section{FUNDING}

No funds were received for conducting this study.

\section{REFERENCES}

Abdulkareem, T. A. and Eidan, S. M. (2014). Reproductive performance of iraqi awassi ewes owned by sheep owners and extension farms in response to flushing and estrus. The Iraqi Journal of Agricultural Sciences, $45(3$ ), 328-334. 
Abecia, J. A. et al. (2007) The effect of melatonin on the reproductive performance of three sheep breeds in Spain, Small Ruminant Research, 69(1-3), pp. 10-16. https://doi.org/10.1016/j.smallrumres.2005.12.018

Alkass, J. E. and Abdulkareem, T. a (2004) Reproductive performance of Iraqi Awassi ewes in response to treatment with equine chorionic gondortropin, Journal of Agricultural Investment, 2 (August), 2000-2003. https://doi.org/10.5713/ajas.17.0660

Beck, N. F. G., Davies, B. and Williams, S. P. (1993) Oestrous synchronization in ewes: The effect of combining a prostaglandin analogue with a 5-day progestagen treatment, Animal Production, 56(2), 207-210. https://doi.org/10.1017/S0003356100021279.

Berhan, A. and Van Arendonk, J. (2006) Reproductive performance and mortality rate in Menz and Horro sheep following controlled breeding in Ethiopia, Small Ruminant Research, 63(3), 297 303. https://doi.org/10.1016/j.smallrumres.2005.03.003

Binns, S. H. et al. (2002) Risk factors for lamb mortality on UK sheep farms. Preventive Veterinary Medicine, 52(3-4), 287-303. https://doi.org/10.1016/S0167-5877(01)00255-0

Buckley, F. et al. (2003). Relationships among milk yield, body condition, cow weight, and reproduction in spring-calved Holstein-Friesians, Journal of dairy science. Elsevier, 86(7), 2308-2319. https://doi.org/10.3168/jds.S0022-0302(03)73823-5

Crosby, T. F., Boland, M. P. and Gordon, I. (1991). Effect of progestagen treatments on the incidence of estrus and pregnancy rates in ewes, Animal Reproduction Science, 24(1-2), 109-118. https://doi.org/10.1016/0378-4320(91)90086-F

Evans, A. C. O. (2003). Ovarian follicle growth and consequences for fertility in sheep', Animal Reproduction Science, 78(3-4), 289-306. https://doi.org/10.1016/S0378-4320(03)00096-4

Galal, S., Gürsoy, O. and Shaat, I. (2008). Awassi sheep as a genetic resource and efforts for their genetic improvement-A review, Small Ruminant Research, 79(2-3), 99-108. https://doi.org/10.1016/j.smallrumres.2008.07.018

Gazal, O. S. et al. (1998). Gonadotropin-releasing hormone secretion into third-ventricle cerebrospinal fluid of cattle: correspondence with the tonic and surge release of luteinizing hormone and its tonic inhibition by suckling and neuropeptide Y. Biology of Reproduction,59(3), 676-683. https://doi.org/10.1095/biolreprod59.3.676

Hailat, N. et al. (1997). Foetal anasarca in Awassi sheep, Australian Veterinary Journal, 75(4), $257-$ 259. https://doi.org/10.1111/j.1751-0813.1997.tb10092.x

Lafi, S. Q. et al. (2009). Factors affecting the reproductive performance of Awassi sheep flocks in northeast of Jordan: An epidemiological study. Tropical Animal Health and Production, 41(8), 1755-1764. https://doi.org/10.1007/s11250-009-9374-Z

Leyva, V., Buckrell, B. C. and Walton, J. S. (1998). Regulation of follicular activity and ovulation in ewes by exogenous progestagen. Theriogenology, 50(3), 395-416. https://doi.org/10.1016/S0093-691X(98)00148-4

Mahboub, H. H. D. et al. (2013). Seroprevalence of Abortion Causing Agents in Egyptian Sheep and Goat Breeds and Their Effects on the Animal's Performance. Journal of Agricultural Science, 5(9), 92-101. https://doi.org/10.5539/jas.v5n9p92

Mandal, A. et al. (2007). Factors associated with lamb mortalities in Muzaffarnagari sheep. Small Ruminant Research, 71(1-3), 273-279. https://doi.org/10.1016/j.smallrumres.2006.07.010

Menzies, P. I. (2011). Control of Important Causes of Infectious Abortion in Sheep and Goats. Veterinary Clinics of North America - Food Animal Practice. Elsevier Ltd, 27(1), 81-93. https://doi.org/10.1016/j.cvfa.2010.10.011

Mukasa-Mugerwa, M. and (1992). Theriogenology 38:727-734, 1992', Theriogenology, 38(1992), 727-734.

Oramari, R.A., Bamerny, A.O. and Zebari, H.M., (2014). Factors affecting some hematology and serum biochemical parameters in three indigenous sheep breeds. Advances in Life Science and Technology, 21, 56-63.

Quintero-Elisea, J. A. et al. (2011). The effects of time and dose of pregnant mare serum gonadotropin (PMSG) on reproductive efficiency in hair sheep ewes. Tropical Animal Health and Production, 43(8), 1567-1573. https://doi.org/10.1007/s11250-011-9843-Z 
Rawlings, N. C. and Howell, W. E. (1988). The use of estradiol benzoate to manage lambing period in ewes bred at synchronized estrus. Journal of animal science, 66(4), 851-854. https://doi.org/10.2527/jas1988.664851x

Sánchez, J. et al. (2008). Inhibitory effect of selenium supplementation on the reproductive performance in synchronized Merino sheep at range conditions in a selenium-deficient area. Reproduction in Domestic Animals, 43(3), 328-332. https://doi.org/10.1111/j.1439-0531.2007.00904.X

Taha, V. and Alkass, J. E. (2011). A Survey Study Of Sheep And Goats Raised Under Farm Conditions'. Journal of University of Duhok ((Agri. And Vet. Sciences) 14 (2), 120-125.

Tetsuka, M. et al. (1988) . Effect of Fecundin on ovulation rate and prolificacy in Suffolk ewes during the breeding and non-breeding seasons., The Japanese journal of animal reproduction, 34(2), 91-98. https://doi.org/10.1262/jrd1977.34.91

Ungerfeld, R. and Rubianes, E. (2002). Short term primings with different progestogen intravaginal devices (MAP, FGA and CIDR) for eCG-estrous induction in anestrus ewes. Small Ruminant Research, 46(1), 63-66. https://doi.org/10.1016/S0921-4488(02)00105-0

Wildeus, S. (1997). Hair Sheep Genetic Resources and Their Contribution to Diversified Small Ruminant Production in the United States. Journal of Animal Science, 75(3), 630-640. https://doi.org/10.2527/1997.753630x

Zebari, H. M., Rutter, S. M. and Bleach, E. C. L. (2018). Characterizing changes in activity and feeding behaviour of lactating dairy cows during behavioural and silent estrus. Applied Animal Behaviour Science, 206, 12-17. https://doi.org/10.1016/J.APPLANIM.2018.06.002

Zebari, H.M., (2020). Factors that influence on reproductive efficiency in karadi and awassi sheep raised under traditional conditions. Journal of Duhok University, 23(2), 169-181. https://doi.org/10.26682/ajuod.2020.23.2.20

Zebari, H.M., (2019). Investigations of factors that influence oestrus expression in dairy cattle (Doctoral dissertation), Harper Adams University. 